\title{
OSOBNOSTNÍ ROZVOJ PŘI ZOTAVOVÁNí SE ZE ZÁVISLOSTI NA OMAMNÝCH LÁTKÁCH
}

\author{
Alena Olivová, Alena Slezáčková
}

\begin{abstract}
Abstrakt
Mnohé se ví o negativních dopadech závislostí na kvalitu života - at' jde o dopady ve fyzické či psychosociální rovině. Na pozadí se však mohou odehrávat důležité transformativní změny osobnosti, kterým by měla být věnována stejně tak významná část pozornosti. Tato přehledová studie nabízí souhrn dosavadních poznatků, které se zaměřují na aspekty osobnostního rozvoje následujícího po období aktivního užívání a závislosti na návykových látkách. Popisuje a integruje výsledky z devíti empirických studií jediných, které v kontextu adiktologie zmiňují osobnostní rozvoj a splňují kritéria výběru. Tyto studie jsou dále diskutovány, je poukazováno jak na nejednotné př́stupy ve volbě výchozích teoretických konceptů a jejich výzkumných designů, tak na různorodost výzkumných souborů, například co do typu omamné látky, na které u respondenta vznikla závislost, tak co do množství prodělaných recidiv a léčeb či způsobu léčby. Z přehledu citovaných studií vyplývá, že význam zotavování ze závislosti jde mnohem dále, než je pouhá abstinence. Na případné profitování ze závislosti výzkumníci v současné době nahlížejí z různých výchozích pozic, shodují se však v mnohých závěrech, jako je například důležitost sociální opory, vnímání procesu zotavení jako př́ležitosti k novému životu či zesílení pocitovaného smyslu života. Studie upozorňuje na důležitou a doposud málo prozkoumanou oblast práce $\mathrm{s}$ adiktologickou klientelou, která v praxi může přispět ke stabilitě v procesu zotavování ze závislosti, zvýšení kvality života a k osobnostnímu rozvoji.
\end{abstract}

Klíčová slova: osobnostní rozvoj, závislost, omamné látky, zotavování

\section{PERSONAL GROWTH IN SUBSTANCE ABUSE RECOVERY}

\section{Abstract}

There is a lot known about how drug use and addiction affect a person's life - with both negative physical and psychosocial outcomes. When coping with adverse events some positive transformative changes can be shown and that should be the matter of our interest as well. This review aims to gather, describe and integrate the results of nine empirical studies focused on personal growth associated with recovery from addiction. We had found diverse theoretical approaches as well as different methodology and survey sample characteristics within studies, such as the difference in groups of substances abused by respondents, number of their relapses and treatments as well as the treatment programs they went through. Review findings show that recovery goes beyond abstinence. The studies agree on the importance of social support, perceiving recovery as an ongoing process of growth and an opportunity to start a new life or find meaning in life even though the perspectives of the researchers vary. The article points out the research gap in addiction treatment, which may encourage the clients to profit from their addict's experiences, use them to support the recovery process, and boost their quality of life and personal growth.

Keywords: personal growth, addiction, narcotic drugs, recovery

Došlo: 29. 9. 2020

Schváleno: 4. 2. 2021 


\section{Úvod}

Otázkami osobnostního rozvoje, naplnění vnitřního potenciálu a smysluplnosti života se od počátku 21. století začala na poli vědy zabývat pozitivní psychologie, která přinesla hlubší porozumění korelátům a prediktorům duševního zdraví a osobní pohody a obrátila pozornost $\mathrm{k}$ silným stránkám charakteru a rozvoji osobnosti (Seligman \& Csikszentmihaly, 2000; Slezáčková, 2012). Za specifické výzkumné téma lze považovat otázku osobnostního rozvoje po prožitém traumatu či stresové události. Od počátku 21. století vznikla řada teoretických konceptů, které se tento proces snaží definovat a operacionalizovat. Posttraumatický rozvoj (ang. post-traumatic growth) lze vymezit jako zisk či obohacení o něco nového po prožité ztrátě, traumatu či závažné stresové události a je možným důsledkem dlouhodobého terapeutického procesu (Joseph, 2012; Mareš, 2012; Tedeschi \& Calhoun, 1995, 1998). K jeho dosažení je žádoucí, aby byl klient otevřen zkoumání traumatizující události, uvažování o této nepříznivé situaci v nových perspektivách a nalézání zdrojů k svému vnitřnímu rozvoji (Joseph, 2012). Mezi základní dimenze posttraumatického rozvoje osobnosti patři změna postoje k sobě samému - pocit vnitřní síly, otevřenost novým možnostem, větší sebedůvěra, dále změny v oblasti interpersonálních vztahů, hodnotových priorit, v úctě $\mathrm{k}$ životu, spiritualitě a ve zdraví podporujícím chování (Sears, Stanton \& Danoff-Burg, 2003; Tedeschi \& Calhoun, 1995; Woodward \& Joseph, 2003).

V rámci zkoumání osobnostního rozvoje po zažité nepř́iznivé události vznikly také další koncepty, jako je rozvoj související se stresem (ang. stress-related growth), který značí „změnu k lepšímu“ po prožité závažné události či sledu několika stresujících zkušeností (Caserta et al., 2009; Park et al., 1996). V odborné literatuře věnované posttraumatickému rozvoji se setkáme i s dalšími př́buznými termíny: zkoumání pozitivních psychologických změn (Yalom \& Lieberman, 1991), rozvoj iniciovaný negativními událostmi a neštěstím (ang. adversarial growth, Linley \& Joseph, 2004; Mareš, 2012), odolnost jedince (ang. resilience) a prospívání (ang. thriving), kdy jedinec přerámovává trauma jako výzvu, díky níž se posouvá na vyšší úroveň než dříve (Mareš 2012; O'Leary et al., 1998), či vnímaný (ang. perceived benefit) a konstruovaný př́nos (ang. construed benefit) (Calhoun \& Tedeschi, 1991; Tennen et al., 1992). Všechny zmíněné př́stupy sjednocuje zážitek rozvoje - tedy že se osoba po náročné, traumatizující stresové události anebo po delším zátěžovém období nevrací na svoji výchozí pozici, ale překračuje ji a díky tomu se dále rozvíjí. V literatuře se můžeme setkat také s tzv. „,bounce-back“ efektem, který je spjat především s konceptem odolnosti (ang. resilience), jakožto schopnosti docílit změny, učit se a posilovat sám sebe v důsledku nepř́źznivých okolností (Begley, 2019; Collier, 2016). V souvislosti s posttraumatickým rozvojem je třeba uvést na pravou míru rozdíl v reakcích na nepř́iznivou událost tak, jak jej chápe koncept odolnosti oproti konceptu posttraumatického rozvoje. Vysoká odolnost jedince umožňuje jeho „bounce-back“ proces snáze než je tomu u posttraumatického rozvoje, přičemž se osoba nemusí rozvíjet a dostávat nad svoji původní úroveň, ale pouze se do této výchozí pozice vrátit. Naopak při posttraumatickém rozvoji je zjevný posun dopředu, celý proces benefitování ze zkušenosti je náročnější a zároveň je nepříznivější i výchozí stav či okolnosti jedince a jeho života (Begley, 2019). Může tedy znamenat časově náročnější a mnohdy také bolestný proces (Collier, 2016).

Dalším př́stupem, který zkoumá oblasti osobnostního rozvoje, je uplatňování tzv. benefitfinding strategií - tedy strategií spočívajících ve schopnosti jedince benefitovat z obtížné situace a nacházet v ní pozitiva (Tennen \& Affleck, 2002). Perspektivou, skrze níž lze nahlížet na projevy osobnostního rozvoje, může být také zkoumání subjektivního hodnocení prožité zkušenosti, 
v kontextu naší studie tedy zkušenosti zotavovacího procesu po období aktivního užívání omamných látek.

Novější studie věnované posttraumatickému rozvoji zpracovávají téma osobnostního rozvoje následujícího po prožití osobního traumatu, např. úmrtí dětí či blízkých osob (Kursheed \& Shahnawaz, 2020), anebo přírodní katastrofy (Seo \& Lee, 2020; Zhou et al., 2019), u obětí teroristických útoků (Zeidner \& Kampler, 2019) či násilných činů (Anderson et al., 2019; Kirkner \& Ulman, 2019; Lahav et al., 2019) a u válečných veteránů (Whealin et al., 2020). Téma je také často prozkoumáváno v souvislosti s chronickými onemocněními (napr. Chen et al., 2019; Kuswanto et al., 2020; Liu et al., 2020). Otázce osobnostního rozvoje po prožité závislosti na omamných látkách je však stále věnována jen malá pozornost.

Jako první představili koncept „rozvoje souvisejícího se závislostí“ (ang. addiction-related growth) Haroosh a Fredmanová (2017), kteří poukázali na možný osobnostní rozvoj po překonání závislosti, respektive po skončení období aktivního užíání. Nepublikovaná studie Washtona (2007) poukazuje na výskyt rysů posttraumatického rozvoje u osob po zotavení se ze závislosti v obdobné podobě, jako je tomu u osob po prožité traumatizující události (Washton, 2007, In: Haroosh \& Freedman, 2017). Další indicie, které mohou podpořit úvahy nad souvislostmi závislostí a osobnostního rozvoje, nabízí kompilace níže vyhledaných studií.

\section{Psychosociální a zdravotní důsledky závislostí}

Problematika závislosti na omamných látkách je v České republice významné společenské téma. Mezinárodní srovnávací statistika Organizace pro hospodářskou spolupráci (2020) z roku 2018 staví Českou republiku např́iklad ve spotřebě alkoholu po Litvě, Rakousku a Francii na čtvrté místo s množstvím konzumovaného alkoholu 11,6 litrů čistého alkoholu za rok na osobu. V průběhu posledních let lze v naší zemi sledovat konstantní stav ve spotřebě lihovin (rok 2013: 11,5 1.; 2014 : 11,9 1.; 2015: 11,5 1.). V České republice pije více než 1,5 milionu obyvatel alkohol rizikově a u půl milionu těchto osob má konzumace alkoholu škodlivé dopady na fyzické či psychické zdraví (Národní monitorovací středisko pro drogy a závislosti, 2017; Světová zdravotnická organizace, 2018).

Přestože existuje mnoho poznatků o negativních důsledcích závislosti pro kvalitu života, jež zdůrazňují př̀evážně její nepříznivé dopady ve fyzické, sociální i psychické rovině (Burns \& Teesson, 2002; Fox et al., 2013; Hjorthøj et al., 2015; Newcomb \& Locke, 2005; Schepil et al., 2020; Schulte \& Hser, 2013; Stoto, 2015), novější výzkumy upozorňují i na př́iznivější souvislosti užívání návykových látek.

Ze zdravotních a psychických benefitů z užívání alkoholu lze zmínit např. nižší riziko diabetes a srdečního selhání (De Gaetano et al., 2016; Larsson et al., 2018), zlepšení pamět’ových dovedností u starších osob (Sayed \&, French, 2016; Whiteman, 2015), navýšení HDL cholesterolu či snížené riziko deprese (Gémes et al., 2019). Jejich projevení však autoři podmiňují nutností tzv. umírněné neboli nízkorizikové konzumace, která nespadá do kategorie excesivního či škodlivého užívání. Nízkorizikovým užíváním se poté rozumí takové uživání omamné látky (většinou použiváno v kontextu pití alkoholu), které není škodlivé pro jedince ani pro společnost. V České republice je za míru nízkorizikového pití považována maximální denní dávka $16 \mathrm{~g}$ etanolu pro ženy a $24 \mathrm{~g}$ pro muže, minimálně s dvěma dny v týdnu, kdy jedinec nepije alkohol vůbec (Ruprich, 2015). Ohledně zdravotních benefitů umírněné konzumace alkoholu je tedy nutno zohlednit, že potřebná dávka, která může pozitivní efekt vyvolat (např. kardioprotektivní účinek či snížené riziko diabetes; 
De Gaetano et al., 2016; Larsson et al., 2018; Peele, 2000; Whiteman, 2015), nemusí mít příznivý efekt na jiné části organismu (Peele, 2000; Miovský, 2017). V tomto kontextu je tedy žádoucí zvažovat individuální charakteristiky jedinců a tím i nepředvídatelnou rizikovost umírněné konzumace.

Co se týče zkoumání zdravotních či duševních benefitů v případě uživání nealkoholohových omamných látek, pozornost výzkumníků se obrací k oblasti cannabinoidů a psychedelických látek, a to především jejich terapeutickému potenciálu či užívání velmi malých, subterapeutických dávek látky, formou tzv. mikrodosingu (Anderson et al., 2019; Polito et al., 2019; Ross, 2018). Studie z posledních let (Campell et al., 2019, Devinsky et al., 2017, Rong et al., 2017; Walsh et al., 2017) také poukazují na možné zdravotní benefity při užívání lékařských cannabinoidů v mírnění chronických bolestí a epileptických záchvatů u farmakorezistentních pacientů, při bolestných stavech spojených s roztroušenou sklerózou a rakovinou, dále jako prevence diabetes, při léčbě úzkostí, PTSD, ADD/ADHD, autismu či Parkinsonovy choroby.

\section{Osobnostní rozvoj v kontextu závislosti}

Na závislost může být nahlíženo jako na chronické onemocnění a zotavování se ze závislosti je dlouhodobý, celoživotní proces (Fišerová, 2000). V léčbě závislostí, kterou se zabývá adiktologie, se uplatňuje komplexní bio-psycho-socio-spirituální model (Kalina, 2003). Psychoterapie v adiktologii má význam nejen pro porozumění příčinám a principům závislosti, ale také pro tvorbu terapeutického vztahu, rozvíjení emocionálně korektivních zkušeností či učení se a posilování žádoucích vzorců chování (Kalina, 2013). V terapeutickém procesu dochází u klientů k bližšímu poznání své osobnosti, reflexi dosavadních zkušeností, vědomému zaměření se na vlastní prožívání a podstoupení terapeutických intervencí $\mathrm{k}$ jeho ovlivnění. Odehrává se práce na sobě samém směrem k žádoucí změně, která má v sobě velký rozvojový potenciál (Roubal \& Vybíral, 2010; Yalom, 2012).

Výzkumů životních zkušeností osob léčících se ze závislostí zatím v českém prostředí není mnoho. Samková a Dolejš (2014) zkoumali smysluplnost života u mužů hospitalizovaných pro závislost na alkoholu a odhalili nižší úroveň pocit’ovaného smyslu života. Nižšś míru smysluplnosti života a výskyt existenciální neurózy byl potvrzen u respondentů s přidruženou závislostí $\mathrm{k}$ alkoholismu a u mladších jedinců. Respondenti také uváděli, že se po léčbě chtějí orientovat na partnerství a výchovu dětí, což vnímají jako smysl jejich života po skončení léčby. Stejně tak závěry Kavenské (2009) poukazují na proměnlivost ve vnímání smyslu života v průběhu léčby i v následné fázi udržování abstinence po jejím skončení.

V současné době se upouští od paradigmatu zotavování, které je rovno úplné abstinenci, a důraz je kladen nejen na chemické zotavení, ale také zotavení emocionální (Wilson, 1958, dle elGuebaly, 2012). Zotavování můžeme chápat jako proces překonávání, získávání se změnami v kognitivní, emocionální, behaviorální a spirituální rovině (Mee-Lee et al., 2001; Ries et al., 2014; White, 2007). Život v abstinenci ani závislost samotnou však nelze znázornit pouze etapami remisí a relapsů. Jde o dynamický proces, $v$ jehož rámci se osoba snaží navracet do původního stavu před užíváním a stabilizovat se.

Tato přehledová práce přináší přehled zatím málo prozkoumaných aspektů osobnostního rozvoje v kontextu závislosti na omamných látkách. Jejím cílem je zmapovat studie, které se z různých úhlů pohledu věnují tématu osobnostního rozvoje v kontextu závislosti, pokusit se je utř́dit a kriticky okomentovat a nabídnout doporučení pro využití poznatků v adiktologické praxi. 


\section{Metoda}

Tato přehledová studie čerpá z odborné literatury publikované v anglickém a českém jazyce, a to z výzkumů publikovaných po roce 2000 , kdy se začal rozvíjet obor pozitivní psychologie, jenž přinesl termín ,posttraumatický rozvoj osobnosti“. Studie byly vyhledané za použití databází EBSCO Academic Search Ultimate, Scopus a PsycINFO se zadáním klíčových slov addict* or dependen* or abus* (titul) AND drug* or alcohol* or substance* or recovery* (titul) AND growth* or benefit* or positive* or *personal* or ,posttraumatic growth“ or PTG or stress-related* or „,benefit finding“ (titul) AND recover* or treatment* or follow* or post* (tématický termín). Zaměřovali jsme se na takové zdroje, jejichž obsah pokrývá či může poukazovat na možné pozitivní dopady na osobnost po období užívání omamných látek spojeném s rozvojem v závislost. Soustředili jsme se na odborné studie, ve kterých je dostatečně popsán výzkumný postup i použitý teoretický koncept. K devíti relevantním výzkumům, které jsou dále popisovány (tab 1, tab 2 a tab 3), jsme dospěli vyhledáváním ve výše uvedených databázích (nalezeno 596 publikací) dle zmíněných zvolených kritérií. Celkové množství publikací bylo zkontrolováno dle názvu a abstraktu, vyloučili jsme duplicitní citace a následně jsme prostudovali jednotlivé plné texty.

\section{Tab 1.}

Diagnostické nástroje použité ve studiích

Addiction Severity Index (ASI; McLellan, 1992)

Adolescent Negative Life Events Inventory (Wills, Cleary, 1996)

Depression Anxiety Stress Scale (DASS; Lovibond, Lovibond, 1995)

Desires for alcohol questionnaire (DAQ; Mo, Deane, Lyons, Kelly, 2013)

Drug Taking Confidence Questionnaire (DTCQ; Sklar, Turner, 1999)

Hardiness Scale: Short form (HS; Bartone, 1989)

Life Engament Test (LET; Scheier, 2006)

Life Orientation Test (LOT; Scheier, Carver, 1985)

Lifetime Drug Use History (LDUH; Day, 2008)

Marlowe-Crowne Social Desirability Scale (MCSD; Crowne, Marlowe, 1960)

Maudsley Addiction Profile (MAP; Marsden, 1998)

Mental Health Continuum - Short Form (MHC-SF; Keyes, 2002)

MINI Mini International Neuropsychiatric Interview (MINI; Sheehan, 1998)

Peer substance use (2000, Sussman, Dent, McCullar)

Perceived Social Support Questionnaire (Zimet, Dahlem, Farley, 1988)

Posttraumatic Growth Inventory (PTGI, Tedeshi, Calhoun, 1996)

Quality of Life (WHOQOL BREF, 2004)

Recovery Group Participation Scale (RGPS; Groshkova, 2011)

Santa Clara Strength of Religious Faith Questionnaire (SCSRF; Plante, Boccaccini, 1997)

Social Provision Scale (SPS; Cutrona, Russell, 1987)

Taylor Manifest Anxiety Scale: Short form (TMA; Bendig, 1956)

WHO quality of life measure (WHOQOL Group, 1998)

Willingness to Seek Help Scale (Cohen, 2016) 
Tab 2.

Charakteristiky výzkumných souborů

\begin{tabular}{|c|c|c|c|c|c|c|c|c|}
\hline Autor (rok) & $\begin{array}{l}\% \\
\text { žen }\end{array}$ & $\begin{array}{l}\text { Průměrný } \\
\text { věk }\end{array}$ & $\begin{array}{l}\text { Rodinný } \\
\text { stav }\end{array}$ & Druh závislosti & $\begin{array}{l}\text { Min. délka } \\
\text { abstinence }\end{array}$ & $\begin{array}{l}\text { Průměrná } \\
\text { délka } \\
\text { závislosti }\end{array}$ & $\begin{array}{l}\text { Pořadí léčby } \\
\text { poslední relaps } \\
\text { délka remise }\end{array}$ & Forma léčby \\
\hline $\begin{array}{l}\text { Arpawong et al. } \\
(2015)\end{array}$ & 45,6 & 16,8 & $\mathrm{n} / \mathrm{a}$ & $\begin{array}{l}\text { alkohol, } \\
\text { marihuana, } \\
\text { tabák, ilegální } \\
\text { drogy } \\
\text { (nespecif.) }\end{array}$ & $\mathrm{n} / \mathrm{a}$ & $\mathrm{n} / \mathrm{a}$ & $\begin{array}{l}49 \% \text { užití drogy } \mathrm{v} \\
\text { posledním roce }\end{array}$ & $\begin{array}{l}\text { léčba ne; účastníci preventivního programu } \\
\text { SSS }\end{array}$ \\
\hline Best et al. (2012) & 33,2 & 42 & $\begin{array}{l}51,7 \quad \% \\
\text { svobodný }\end{array}$ & alkohol, heroin & $\begin{array}{l}59 \% 1-3 \\
\text { roky, } 12,7 \% \\
3-5 \text { let, } \\
28,3 \% \text { nad } 5 \\
\text { let }\end{array}$ & 13,4 let & $\begin{array}{l}\text { n/a (průměrně } 6 \text { let } \\
\text { od posledního užití) }\end{array}$ & $\begin{array}{l}\text { léčba ano; Glasgow Recovery Service (blíže } \\
\text { nespecifikováno) }\end{array}$ \\
\hline $\begin{array}{l}\text { Haroosh, } \\
\text { Fredman (2017) }\end{array}$ & 11 & 40,2 & $\begin{array}{l}33 \% \\
\text { svobodný, } \\
25 \% \% \\
\text { manželství, } \\
37 \% \% \\
\text { rozvedený, } \\
2.9 \% \% \\
\text { ovdovělý či } \\
\text { v odloučení }\end{array}$ & $\begin{array}{l}\text { alkohol, } \\
\text { marihuana, } \\
\text { diethylamid } \\
\text { kyseliny } \\
\text { lysergové } \\
\text { (LSD), extáze } \\
\text { (MDMA), } \\
\text { prášky na } \\
\text { spaní, kokain, } \\
\text { opiáty, } \\
\text { stimulanty, } \\
\text { jiné (nespecif.) }\end{array}$ & $\begin{array}{l}\text { n/a } \\
\text { (respondenti } \\
\text { v léčbě) }\end{array}$ & $\mathrm{n} / \mathrm{a}$ & $\begin{array}{l}1 . \quad(59 \\
\text { respondentů) }\end{array}$ & $\begin{array}{l}\text { léčba ano; Addiction treatment programme } \\
\text { (blíže nespecifikováno) }\end{array}$ \\
\hline $\begin{array}{lll}\text { Kang } & \text { et } \quad \text { al. } \\
(2018) & & \end{array}$ & 40 & 41 & $\begin{array}{l}2 \text { svobodní, } \\
2 \quad \mathrm{v} \\
\text { manželství, } \\
1 \\
\text { rozvedený }\end{array}$ & $\begin{array}{l}\text { metamfetamin, } \\
\text { marihuanna, } \\
\text { kokain / extáze } \\
\text { (MDMA) }\end{array}$ & 3 roky & $\mathrm{n} / \mathrm{a}$ & $\mathrm{n} / \mathrm{a}$ & $\mathrm{n} / \mathrm{a}$ \\
\hline
\end{tabular}




\section{(C) PSYCHOLOGIE

\begin{tabular}{|c|c|c|c|c|c|c|c|c|}
\hline Laudet (2007) & 45,7 & 43 & $\begin{array}{l}56 \% \\
\text { svobodný, } \\
16 \% \text { v } \\
\text { manželství, } \\
28 \% \text { / } \\
\text { ovdovělý } \\
\text { v odloučení } \\
\text { / rozvedený }\end{array}$ & $\begin{array}{l}\text { heroin, crack, } \\
\text { kokain, } \\
\text { alkohol }\end{array}$ & 1 měsíc & $\mathrm{n} / \mathrm{a}$ & $\begin{array}{l}\mathrm{V} \text { remisi nad } 3 \text { roky } \\
40,8 \%, \quad 18-36 \\
\text { měsíců } 16,6 \%, 6-18 \\
\text { měsíců } 12,3 \% \text {, pod } \\
6 \text { měsíců } 29,9 \%\end{array}$ & $\begin{array}{l}\text { léčba ne; přirozené zotavování (bez } \\
\text { zkušenosti z ústavní léčby; výzkum přirozené } \\
\text { role psychosociálních faktorů); } 85,8 \% \text { se } \\
\text { zkušeností s léčbou }\end{array}$ \\
\hline $\begin{array}{l}\text { McGaffin et al. } \\
(2015)\end{array}$ & 20,5 & 36 & $\begin{array}{l}68 \% \\
\text { svobodný, } \\
6,9 \% \text { v } \\
\text { manželství, } \\
13,9 \% \\
\text { rozvedený, } \\
10,8 \% \text { v } \\
\text { odloučení, } \\
0,4 \% \\
\text { ovdovělý }\end{array}$ & $\begin{array}{l}\text { alkohol, } \\
\text { amfetaminy, } \\
\text { marihuana, } \\
\text { heroin, jiné } \\
\text { (nespecif.) }\end{array}$ & $\begin{array}{l}30 \text { dní / } \\
\text { nelimitováno }\end{array}$ & 18,3 let & $\mathrm{n} / \mathrm{a}$ & $\begin{array}{l}\text { léčba ano; Recovery service centre (viz } \\
\text { terapeutická komunita) }\end{array}$ \\
\hline $\begin{array}{l}\text { Pardini et al. } \\
(2000)\end{array}$ & 43,2 & 37,1 & $\mathrm{n} / \mathrm{a}$ & $\begin{array}{l}\text { alkohol, jiné } \\
\text { (nespecif.) }\end{array}$ & $\mathrm{n} / \mathrm{a}$ & $\mathrm{n} / \mathrm{a}$ & $\mathrm{n} / \mathrm{a}$ & n/a; $81 \%$ přechodové byty \\
\hline $\begin{array}{l}\text { Witbrodt et al. } \\
\text { (2015) }\end{array}$ & $\begin{array}{l}> \\
50\end{array}$ & $\begin{array}{lr}\text { n/a } & (3 / 4 \\
\text { věk } & \text { nad } \\
35) & \end{array}$ & $\mathrm{n} / \mathrm{a}$ & alkohol & $\begin{array}{l}\text { nelimitováno } \\
\text { (většina nad } \\
5 \text { let) }\end{array}$ & $\mathrm{n} / \mathrm{a}$ & $\begin{array}{l}\text { v remisi nad } 5 \text { let } \\
56 \%, 1-5 \text { let } 29 \% \\
\text { pod } 1 \text { rok } 15 \%\end{array}$ & $\begin{array}{ll}\text { léčba ano i ne; jen } 4 \% \text { přirozené zotavování, } \\
\text { zbytek ústavní léčba v kombinaci se } \\
\text { svépomocnou } & \text { skupinou } \\
\text { alkoholiků (dále } & \text { AA), bez AA, či pouze } \\
\text { docházka na AA } & \end{array}$ \\
\hline
\end{tabular}


Tab 3.

Metodologické koncepty a výsledky

\begin{tabular}{|c|c|c|c|c|}
\hline Autor (rok) & $\begin{array}{l}\text { Výchozí } \\
\text { teoretický } \\
\text { koncept }\end{array}$ & $\begin{array}{l}\text { Metodologie } \\
\text { výzkumu }\end{array}$ & Metody a diagnostické a nástroje & Relevantní výsledky \\
\hline $\begin{array}{l}\text { Arpawong et } \\
\text { al. (2015) }\end{array}$ & $\begin{array}{l}\text { posttraumatický } \\
\text { rozvoj }\end{array}$ & $\begin{array}{l}\text { kvantitativní, } \\
\text { opakované } \\
\text { měření po } 2 \\
\text { letech }\end{array}$ & $\begin{array}{l}\text { Adolescent Negative Life Events Inventory, } \\
\text { Posttraumatic Growth Inventory, Peer substance use }\end{array}$ & $\begin{array}{l}\text { nižší pravděpodobnost posttraumatického rozvoje (dále PTG) u } \\
\text { jedinců, kteří ve vysoké míře užívali alkohol či marihuanu. } \\
\text { Asociace PTG a cigaret nebo těžkých drog nenalezena. }\end{array}$ \\
\hline $\begin{array}{l}\text { Best et al. } \\
(2012)\end{array}$ & kvalita & & $\begin{array}{l}\text { Quality of Life, Maudsley Addiction Profile, Lifetime } \\
\text { Drug Use History, Recovery Group Participation }\end{array}$ & $\begin{array}{l}\text { lepší kvalita života a zvládání závislosti posíleno účastí v } \\
\text { podpưrné skupině a zapojováním se do smysluplných aktivit }\end{array}$ \\
\hline
\end{tabular}
Scale

\begin{tabular}{|c|c|c|c|c|}
\hline $\begin{array}{l}\text { Haroosh, } \\
\text { Fredman } \\
(2017)\end{array}$ & $\begin{array}{l}\text { posttraumatický } \\
\text { rozvoj } \rightarrow \\
\text { addiction- } \\
\text { related growth }\end{array}$ & $\begin{array}{l}\text { kvantitativní; } \\
\text { průřrezová } \\
\text { studie }\end{array}$ & $\begin{array}{l}\text { Posttraumatic Growth Inventory, Perceived Social } \\
\text { Support Questionnaire, Willingness to Seek Help } \\
\text { Scale }\end{array}$ & spiritualita, nalezení smyslu života, sociální podpora \\
\hline $\begin{array}{l}\text { Kang et al. } \\
(2018)\end{array}$ & $\begin{array}{l}\text { posttraumatický } \\
\text { rozvoj } \rightarrow \\
\text { addiction- } \\
\text { related growth }\end{array}$ & $\begin{array}{l}\text { kvalitativní; } \\
\text { případová } \\
\text { studie }\end{array}$ & polostrukturované rozhovory $(4 \times 90 \mathrm{~min})$ & $\begin{array}{l}\text { návrat do reality (ang. reconnection with reality), sebeláska (ang. } \\
\text { self-love), porozuméní podstatě své existence (ang. embracing the } \\
\text { essence of one's own existence), napravení své role v sociálních } \\
\text { vztazích (ang. reconstructing oneself in social relations) }\end{array}$ \\
\hline Laudet (2007) & $\begin{array}{l}\text { subjektivní } \\
\text { vnímání } \\
\text { významu } \\
\text { zotavování }\end{array}$ & smíšený & $\begin{array}{l}\text { polostrukturovaný rozhovor; MINI Mini } \\
\text { International Neuropsychiatric Interview }\end{array}$ & $\begin{array}{l}\text { zotavení jako příležitost k "novému životu“, stále probíhající } \\
\text { proces rưstu (ang. an ongoing proces of growth), osobnostní } \\
\text { změna (ang. self-change) a opětovná kultivace self (ang. } \\
\text { reclaiming the self) }\end{array}$ \\
\hline
\end{tabular}




\section{$\theta^{\text {enmaname }}$ \\ elektronický časopis ČMPS}

McGaffin et Keyesův model kvantitativní; Mental Health Continuum - Short Form, Addiction al. (2015) longitudinální

longit

studie

opakovaným

měřením po 3

a 12 měsících vyšší míra optimálního prospívání (ang. flourishing) v plné abstinenci, asociace s praktikováním jógy Severity Index, Life Engament Test, Depression
Anxiety Stress Scale, Desires for alcohol

questionnaire, Drug Taking Confidence kvantitativní

Santa

Clara Strength of Religious Faith

Questionnaire, Life Orientation Test, Social Provision

Scale, Taylor Manifest Anxiety Scale: Short-form,

Hardiness Scale: Short-form, Marlowe-Crowne

Social Desirability Scale

\begin{tabular}{|c|c|}
\hline $\begin{array}{l}\text { Witbrodt et } \\
\text { al. (2015) }\end{array}$ & $\begin{array}{l}\text { subjektivní } \\
\text { vnímání } \\
\text { významu } \\
\text { zotavování }\end{array}$ \\
\hline
\end{tabular}

polostrukturovaný rozhovor; MINI Mini International Neuropsychiatric Interview, WHO quality of life measure u osob s vyšší mírou spirituality větší optimismus, více pocit’ovaná sociální podpora, lepší odolnost vưči stresu a nižší míra úzkostnosti pravdivost k sobě samému (ang. being honest with myself),
zvládání negativních pocitů bez užití drogy (ang. handling
negative feelings without using), schopnost užívat si život (ang. being able to enjoy life), proces růstu a rozvoje (ang. process of growth and development) 


\section{Výsledky}

Osm z devíti vybraných studií realizovalo výzkum na souborech složených z osob mužského pohlaví, což odpovídá výzkumným zjištěním, že muži omamné látky užívají ve větší míře a častěji vyhledají léčbu (GBD, 2016; Greenfield, 2010; Holman et al., 1996; National Institute on Alcohol Abuse and Alcoholism, 2008; Substance Abuse and Mental Health Services Administration, 2018; Wolt \& Valachová, 2019). Průměrný věk respondentů citovaných studií je mezi 35-40 lety, a to bez výrazných odchylek. Za nejnáchylnější věkové období k propuknutí závislosti se celosvětově považuje období 20-29 let (GBD, 2016).

$\mathrm{Z}$ údajů zařazených do tabulky 3 je zjevná nejednotnost v použití teoretických konceptů i metodologických přístupů. Různorodost mezi výzkumnými soubory je patrná z tabulky 2. Studie zahrnují respondenty závislé na alkoholu, marihuaně, stimulantech, opiátech i psychedelických látkách, a nejsou shodné co do délky abstinence či množství absolvovaných léčeb respondenti̊.

I přes heterogenitu zkoumaných studií, jež reflektuje současný limitovaný stav poznání $\mathrm{v}$ dané oblasti, se domníváme, že jejich analýza přináší zajímavé výsledky. V následující části jsou představeny a komentovány hlavní oblasti rozvoje následujícího po prožité závislosti.

\section{Př́ležitost k novému životu}

Laudet (2007) a Witbrodt et al. (2015) souhlasně nahlížejí na možné oblasti rozvoje z hlediska subjektivního vnímání procesu zotavování. Uvádějí, že reflexe současného stavu v porovnání $\mathrm{s}$ životem v závislosti a prožívání procesu překonávání své závislosti může vést k posílení uvědomění, že má jedinec kompetenci skončit s užíváním omamných látek a dále že je jeho životní př́iběh plastický, proměnlivý, ne zcela závislý na vnějších podmínkách. Shodují se také ve vnímání zotavování jako stále probíhajícího procesu rozvoje, nezávislého na délce abstinence respondentů či léčby v ústavním anebo $\mathrm{v}$ prrirozeném prostředí. Tyto vnímané př́nosy respondenti popisují v obou studiích (Laudet, 2007; Witbrodt et al., 2015) v rámci polostrukturovaného rozhovoru. Metodologicky jsou si studie podobné také použitím nástroje MINI International Neuropsychiatric Interview (Sheehan, 1998). Witbrodt et al. (2015) měření doplňují nástrojem WHO Quality Of Life Measure (WHOQOL Group, 1998), což je vhodnou podporou pro zjišt'ování výchozího zhodnocení kvality života respondentem. Bývalí uživatelé (ve studii Laudeta, 2007, se jednalo o uživatele heroinu, cracku, kokainu a alkoholu; ve studii Witbrodta, 2015, o uživatele alkoholu) popisují své zotavování jako př́ležitost k novému životu, poukazují na již zmíněnou dynamiku a rozvojový faktor procesu, s tím související schopnost užívat si život a víru ve změnu, dále schopnost zvládat své negativní stavy bez užití omamných látek, pozitivní změny ve struktuře jejich osobnosti a ochotu ke kultivaci sebe samého.

\section{Osobní identita a sociální opora}

Již Biernacki (1986) vyzdvihuje, že dřive závislá osoba si musí vytvořit novou identitu a obrodit svůj vztah ke společnosti, ve které je identita „závisláka“ (ang. addict identity) neprijímána a znehodnocována. Takový proces přechodu k nové identitě a opuštění zvnitřněného stigmatu vyžaduje vývoj včase. Zdravá sociální identita je pak snáze 
dosahována ve svépomocných skupinách Anonymních alkoholiků, a to díky soudržnosti, kohezi a společnému účelu skupiny (Best, 2016). Na významu posílení schopnosti zvládat svoji abstinenci a zvýšit kvalitu svého života díky účasti v podpůrné skupině se shoduje více výzkumů (Best, 2012; Harosh \& Freedman, 2017; McGaffin et al., 2013). Sociální opora je vnímána jako významný faktor snadnějšího zotavování ze závislosti a uvědomování jejího významu je uváděno jako jeden z nabytých prínosů do života (Best, 2012; Haroosh \& Fredman, 2017; Kang, 2018; Pardini, 2000).

\section{Časová dimenze rozvoje}

Studie Kanga et al. (2018), obdobně jako výzkum Harooshe a Fredmanové (2017), vychází z konceptu posttraumatického rozvoje. Přestože se autoři studií rozcházejí v podobě metodologického designu, shodují se v základních aspektech osobnostního rozvoje, mezi něž patři zvýšení hodnoty smyslu života, změna v sebepojetí a již zmíněný význam sociálního zázemí respondentů.

Oproti studii Kanga et al. (2018), kteří prováděli výzkum na respondentech min. 3 roky v abstinenci, Haroosh a Fredmanová (2017) k délce abstinence nepřihlížejí. Výstupy Harooshe a Fredmanové (2017), nezávislé na délce abstinence respondentů, tedy mohou u osob, které byly v abstinenci teprve krátce, obnášet riziko neúplnosti uvědomovaných zisků nebo jejich dlouhodobé neudržitelnosti. Je však možné, že lze plnohodnotně benefitovat z prožitého závislostního způsobu života již v kratším období od započetí abstinence. Minimální délka abstinence a odstupu od závislostního způsobu života se různí i v dalších studiích (Laudet, 2007; Witbrodt et al., 2015), které přinášejí nejednotné výsledky, a měla by být dále zkoumána. V některých studiích (Haroosh \& Fredman, 2017; McGaffin et al., 2015; Pardini et al., 2000) tento faktor není uveden či dostatečně odůvodněn.

\section{Změny ve spiritualitě}

Haroosh a Fredmanová (2007) uvádějí, že překonání závislosti může ústit také v pozitivní změny v oblasti spirituality. Kultivace víry, jež je mj. součástí programu Anonymních alkoholiků, pak může souviset s lepším zvládáním abstinence. Pardini et al. (2000) upozornili, že u jedinců s vyšší mírou spirituality byl také rozpoznán optimističtější přístup k životu, nižší míra úzkostnosti a vyšší odolnost vůči stresu.

\section{Diskuze}

Z přehledu citovaných studií vyplývá, že prospěšným důsledkem zotavování ze závislosti nemusí být pouhá absence návykové látky, ale může docházet i k pozitivním změnám a osobnostnímu rozvoji. Tento proces je podmíněn vícero faktory, jakými jsou např. forma léčby, účast $\mathrm{v}$ podpůrných skupinách, docházka na terapii i samotný motiv a schopnost uvědomovat si benefity a ztráty v procesu zotavování. Pozitivní změny mohou být podpořeny terapeutickou péčí a cílenými intervencemi, avšak jejich empirickému ověření zatím výzkumníci nevěnují pozornost a zaslouží si tedy další zkoumání. 
S ohledem na trvání léčby a schopnosti její reflexe k uvědomování dopadů ze zotavování se výsledky studií různí. Bútora (2008) popisuje rozmezí 3-5 let od počátku abstinence jako fázi uzdravování, ve které dochází k upevnění racionální, behaviorální a emocionální složky postoje $\mathrm{k}$ prožité závislosti a tedy i schopnosti nahlédnout a zhodnotit př́nosy $\mathrm{z}$ období aktivního užívání.

Pokud si klient začne uvědomovat schopnost změnit svůj životní styl a přestat užívat omamné látky, může se v procesu zotavování zvyšovat úroveň jeho sebeúčinnosti (selfefficacy), která má významný vliv na předejití či následné zvládnutí relapsu (Ibrahim et al., 2011; Nikmanesh et al., 2017). Je tedy důležité zvažovat, jak lze nárůst sebeúčinnosti posilovat. V terapeutickém či poradenském kontaktu se může jednat např. o předávání kompetencí a zodpovědnosti klientovi, reflektování jeho úspěchů, učení se z chyb anebo podpora ke vzájemnému setkávání se v rámci peer skupin - vedených podpůrných či svépomocných.

Jedním z uváděných benefitů prodělané závislosti je také vyšší schopnost zvládat negativní pocity bez omamných látek (Witbrodt et al., 2015) a zvýšení odolnosti vůči stresu (Pardini et al., 2000). K lepšímu zvládání negativních stavů a k optimističtějšímu prístupu k životu přispívá i vyšší míra spirituality (Pardini et al., 2000), která je také dle Nešpora a Csémyho (2006) spojena s méně častým pitím alkoholu v tazích a se sníženou potřebou kouřit cigarety. Role spirituality, kultivace víry a s tím spojených hodnot je významnou složkou setkávání svépomocných skupin Anonymních alkoholiků/narkomanů, jejichž vliv na efektivitu léčby (např. Fromson \& Shah, 2014; Lookatch et al., 2019) i pocit'ovanou kvalitu života (Mokhtari et al., 2019) dokazují mnohé výzkumy. Za smysluplné se dokonce jeví i zařazení spirituálního obsahu do vzdělávacích sylabů personálu, který $\mathrm{s}$ osobami procházejícími zotavovacím procesem může dále interagovat a posilovat jejich duševní pohodu (Worley, 2020). Jakési existenciální vakuum, které vyplývá z nenaplnění duchovní podstaty a potřeb osob, je některými autory dokonce považováno za příčinu vedoucí $\mathrm{k}$ užívání omamných látek (Riesel, 2017). Na skutečnost, že závislostní chování může vzniknout jako důsledek narušené integrace fyzické, emoční, duševní a duchovní oblasti jedincova života, ostatně upozornil již Jung (1992).

Na rozdíl od výše uvedených výzkumů, jež odhalily příznivé aspekty rozvoje po prožité závislosti, studie Arpawonga et al. (2015) existenci posttraumatického rozvoje po užívání omamných látek nepodporuje. Autoři také poukazují na nižší pravděpodobnost posttraumatického rozvoje u jedinců, kteří v životě zažili vysoce stresovou událost (jako např. konflikty v rodině, nemoci či úmrtí blízkých, ekonomické obtíže, ...) a ve vysoké míře užívali alkohol či marihuanu, než tomu bylo u osob s obdobným stresovým pozadím, které alkohol či marihuanu neužívaly vůbec či tyto látky konzumovaly rekreačně. Ani souvislost posttraumatického rozvoje s kouřením nebo užíváním nelegálních látek potvrzena nebyla.

I když tedy v této výzkumné oblasti doposud nepanuje shoda, u studií zabývajících se přínosy v procesu zotavování (Laudet, 2007; Witbrodt et al., 2015) považujeme za významný především jejich destigmatizační potenciál. Laická populace často vnímá abstinenci či zotavování se ze závislosti především jako absenci požívání určité látky či nežádoucí činnosti a závislost pouze jako úpadek osobnosti. Tato kvantitativní orientace však opomíjí možný proces seberozvoje a zažívaných změn jak u osob v abstinenci po prožité závislosti, 
tak mimo jiné i při dobrovolném abstinování zdravých jedinců. Neblahé dopady závislosti na život jedince i jeho osobnost jsou nesporné, príitomnost stigmatu „,alkoholika“ však vytváŕí abstinujícím osobám nárok na osvojení této „nálepky“ a znesnadňuje tak udržitelnost jejich stavu v abstinenci. Sociální stigma může být zároveň důvodem, pro který jedinec nevyhledá léčbu. Tento fenomén se projevuje obzvláště u žen (Greenfield, 2010). Snahou o destigmatizaci a zvyšování povědomí společnosti jak o onemocnění samotném, tak o prrínosech z abstinence, lze výrazně napomoci ke snadnějšímu přijetí onemocnění, a tak i méně stresovému prožívání osob se závislostí. McGaffin et al. (2015) dokonce poukazují na vyšší úroveň optimálního prospívání ve smyslu „flourishing“ u osob v plné abstinenci, než je tomu u jedinců $\mathrm{z}$ běžné populace nebo u osob se závislostními potížemi, kteří látku užívají kontrolovaně či nárazově. Pro zlepšení duševního zdraví a benefitování v procesu zotavování je tedy důležitější spíše než kontrolované užívání plná abstinence.

\section{Limity}

Vzhledem $\mathrm{k}$ tomu, že zpracovávané téma je v zahraničním i tuzemském kontextu relativně nové a málo prozkoumané, je nutné zohlednit několik limitací. Citované studie pracují se závislostmi různých látkových skupin v malém počtu respondentů. Takový nejednotný vzorek může u kvantitativních studií poukazovat na jeho nedostatečnou reprezentativnost a znemožňovat zobecnění závěrů na širší populaci. Pro lepší porozumění zkoumanému tématu tedy považujeme za vhodné provádět výzkumy tohoto typu u uživatelů jednotlivých látkových skupin.

Za určitý limit lze považovat i nepoměrné zastoupení mužů a žen ve sledovaných studiích. Dosavadní poznatky však opakovaně poukazují na převahu mužů ve vyhledání léčby a účasti na ní, což však do značné míry odráží stávající realitu - v léčebných zařízeních se častěji setkáváme s mužskými klienty než s ženskými klientkami. Taková skutečnost může souviset s určitými genderovými specifiky ženského pohlaví, jako je péče o děti, těhotenství, větší zaobírání se sociálním stigmatem i společensky nižší mírou přijatelnosti žen pijanek, či jejich omezenými finančními možnostmi (Greenfield, 2010).

Stejně tak existují odlišnosti v přihlížení k možným třetím faktorům, které mohou výstupy studií ovlivnit - např. zařazení či vyloučení osob s duálními diagnózami či celková délka závislosti jedinců. Tento faktor byl zmíněn pouze ve dvou studiích (Best, 2012; McGaffin, 2015) a v průměru se jednalo o 16 let trvání závislosti. Není zjišstováno ani pořadí léčby či délka remise a zřídka je brán $\mathrm{v}$ úvahu psychický stav uživatelů před započetím období aktivního užívání omamných látek vedoucího k rozvoji závislosti. Díky tomu vyvstává otázka, nakolik je proces zkoumání oblastí rozvoje zavádějící v tom, že jsou citované výzkumy citlivé především na př́itomnost pozitivních aspektů s opomenutím negativních dopadů, a jak moc jsou výsledky ovlivněné nastavením osobnosti a predispozicemi, které by byly $\mathrm{v}$ povaze osoby nezávisle na prožité závislosti. Tato zmíněná rizika mohou být snížena např. pravděpodobnostním výběrem respondentů, zjišt'ováním struktury osobnosti psychodiagnostickými metodami a neakcentováním pouze pozitivních aspektů, ale zaměřením se komplexně na dopady života se závislostí, a to jak na ty př́nosné, tak ztrátové a nežádoucí. Jednotlivé studie se dále rozcházejí v použité metodologii od standardizovaných diagnostických nástrojů po kvalitativní metody. 
Také zdravotní benefity z konzumace omamných látek jsou předmětem výzkumných sporů a při zjištění možných přínosů z jejich umírněného uživání je nutné brát $\mathrm{v}$ potaz vedlejší efekty, zvážit podmínky, za kterých může být očekávaný př́nos projeven, a míru negativních dopadů na tělo a psychiku jedince.

V otázce studia faktorů souvisejících se zotavováním ze závislosti je také potřeba zohlednit význam sociokulturních podmínek. V České republice oproti mnoha jiným státům Evropy panuje vyšší sociální tolerance návykových látek (primárně alkoholu), jejich větší medializace i snadná dostupnost, což přispívá k rostoucímu počtu závislých osob.

Přestože je osobnostní rozvoj v kontextu závislostí doposud málo prozkoumanou oblastí, jedná se o důležité téma, jež může přispět k hlubšímu porozumění procesu zotavování, tak také k podpoření procesu učení se ze zkušenosti a zlepšení kvality jedincova života.

\section{Závěr}

Ke zkoumání oblastí osobnostního rozvoje u osob se závislostí na omamných látkách je třeba přistupovat $\mathrm{s}$ patřičnou obezřetností. Pro objektivní a hodnotná zjištění je žádoucí provádět svá zkoumání nestranně, citlivě a co nejkomplexněji s neopomíjením rizik a negativních dopadů z období aktivního užívání. Samotné definování období, odkdy se pravidelné užívání stává rizikovým, je nesnadné. Hranice toho, co je již škodlivé a co vede k rozvoji nežádoucích důsledků, může být i v individuálních př́padech obtížně rozpoznatelná, a proto je nelehké ji zevšeobecnit. Za pozornost stojí také skutečnost, že výzkumy závislostí se zaměřují především na osoby s diagnostikovanou závislostí a nezohledňuje se velká část aktivních uživatelů omamných látek s potenciálním rizikem rozvoje závislosti, kteří se ještě do fáze závislosti nedostali či jejich závislostní jednání nebylo formálně potvrzeno.

Téma osobnostního rozvoje po zkušenosti se závislostí na omamných látkách je nové a aktuální, přitom se vztahuje ke společensky závažné problematice. Př́inos je především co do obohacení uvědomování respondenta (např. v rámci terapeutického kontaktu) o možné rozvojové oblasti a poukázání na prospěšná či zdrojová místa, na které se lze při práci $\mathrm{s}$ klientelou se závislostí na omamných látkách zaměřit. V souladu s teorií posttraumatického rozvoje předpokládáme, že se tyto rozvojové oblasti objevují až po delším období od ukončení období aktivního užívání - po stabilizaci klienta, která umožňuje prohloubení a pochopení jeho životní zkušenosti a nabízí více prostoru věnovat se rozvojovým oblastem. Současně je tato otázka pro nejednotnost názorů v délce období, potřebného k projevení se rozvojových oblastí nadále předmětem diskuze, proto by tématu měla být věnována větší výzkumná pozornost. 


\section{Literatura}

Anderson, K., Delić, A., Komproe, I., Avdibegović, E., Ee, E. \& Glaesmer, H. (2019). Predictors of posttraumatic growth among conflict-related sexual violence survivors from Bosnia and Herzegovina. Conflict andHealth, 13(23). https://doi.org/10.1186/s13031-019-0201-5.

Anderson, T., Petranker, R., Rosenbaum, D., Weissman, C. R., Dinh-Williams, L.-A., Hui, K., Hapke, E. \& Farb, N. A. S. (2019). Microdosing psychedelics: Personality, mental health, and creativity differences in microdosers. Psychopharmacology. 236(2), 731-740. https://doi.org/ 10.1007/s00213-018-5106-2

Arpawong, T. E., Sussman, S., Milam, J. E., Unger, J. B., Land, H., Sun, P. \& Rohrbach, L. A. (2015). Post-traumatic growth, stressful life events, and relationships with substance use behaviors among alternative high school students: A prospective study. Psychology \& Health, 30(4), 475-494. https://doi.org/10.1080/08870446.2014.979171

Bartone, P. T., Ursano, R. J., Wright, K. M. \& Ingraham, L. H. (1989). The impact of a military air disaster on the health of assistance workers: a prospective study. Journal of Nervous and Mental Disease, 177, 317-328. https://doi.org/10.1097/00005053-198906000-00001

Begley, S. (2019). The Science of Bouncing Back from Trauma. Mindful. https://www.mindful.org/the-science-of-bouncing-back-from-trauma/

Bendig, A. W. (1956). The development of a short form of the manifest anxiety scale. Journal of Consulting Psychology, 20, 384. https://doi.org/10.1037/h0045580

Best, D., Beckwith, M. \& Haslam, C. (2016). Overcoming alcohol and other drug addiction as a process of social identity transition: the social identity model of recovery. Addiction Research \& Theory, 24(2), 111-123. https://doi.org/10.3109/16066359.2015.1075980

Best, D., Gow, J., Knox, T., Taylor, A., Groshkova, T. \& White, W. (2012). Mapping the recovery stories of drinkers and drug users in Glasgow: Quality of life and its associations with measures of recovery capital. Drug and Alcohol Review, 31, 334-341. https://doi.org/10.1111/j.14653362.2011.00321.x

Biernacki, P. (1986). Pathways from heroin addiction: Recovery without treatment. Temple University Press.

Burns, L. \& Teesson, M. (2002). Alcohol use disorders comorbid with anxiety, depression and drug use disorders. Drug and Alcohol Dependence, 68(3), 299-307. https://doi.org/10.1016/s03768716(02)00220-x

Bútora, M. (2008). Štádiá uzdravovania v terapii alkoholizmu: trauma začiatku a dráma pokračovania. Psychiatria, psychoterapia, psychosomatika, 15, 102-116.

Calhoun L. G. \& Tedeschi, R. G. (1991). Perceiving benefits in traumatic events: Some issues for practicing psychologists. Journal of Training \& Practice in Professional Psychology, 5(1), 45-52.

Campbell, G., Stockings, E. \& Nielsen, S. (2019). Understanding the evidence for medical cannabis and cannabis-based medicines for the treatment of chronic non-cancer pain. European Archives of Psychiatry and Clinical Neuroscience. 1, 135-144. https://doi.org/10.1007/s00406-018-0960-9

Caserta, M., Lund, D., Utz, R., \& de Vries, B. (2009). Stress-related growth among the recently bereaved. Aging \& Mental Health, 13(3), 463-476. https://doi.org/10.1080/13607860802534641

Cohen, B. (2016). Measuring the willingness to seek help. Journal of Social Service Research. 26(1), 67-82. https://doi.org/10.1300/J079v26n01

Collier, L. (2016). Growth after trauma. Why are some people more resilient than others - and can it be taught? American Psychological Association. https://www.apa.org/monitor/2016/11/growthtrauma

Crowne, D. P., \& Marlowe, D. (1960). A new scale of social desirability independent of psychopathology. Journal of Consulting Psychology. 24, 349-354. https://doi.org/10.1037/h0047358

Cutrona, C. E., \& Russell, D. W. (1987). The provisions of social relationships and adaptation to stress. In W. H. Jones, \& D. Perlman (eds.), Advances in personal relationships. JAI Press.

Day, E., Best, D., Cantillano, V., Gaston, V., Nambamali, A. \& Keaney, F. (2008). Measuring the use and career histories of drug users in treatment: Reliability of the Lifetime Drug Use History 
(LDUH) and its data yield relative to clinical case notes. Drug and Alcohol Review, 27, 175-181. https://doi.org/10.1080/09595230701829504

De Gaetano, G., Costanzo, S., Di Castelnuovo, A., Badimon, L., Bejko, D., Alkerwi, A., ChivaBlanch, G., Estruch, R., La Vecchia, C., Panico, S., Pounis, G., Sofi, F., Stranges, S., Trevisan, M., Ursini, F., Cerletti, C., Donati, M. B. \& Iacoviello, L. (2016). Effects of moderate beer consumption on health and disease: A consensus document. Nutrition, Metabolism and Cardiovascular Diseases, 26(6), 443-467. https://doi.org/10.1016/j.numecd.2016.03.007

Devinsky, O., Cross, J. H. \& Wright, S. (2017). Trial of cannabidiol for drug-resistant seizures in the Dravet Syndrome. New England Journal of Medicine. 376(21). 2011-2020. https://doi.org/10.1056/NEJMc1708349

El-Guebaly, N. (2012). The meanings of recovery from addiction: evolution and promises. The Journal of Addiction Medicine, 6(1), 1-9. doi: https://doi.org/10.1097/ADM.0b013e31823ae540

Fišerová, M. (2000). Historie, příčiny a léčení drogových závislostí. Postgraduální medicína, 2(3), 288-298.

Fox, T. P., Oliver, G. \& Ellis, S. M. (2013). The destructive capacity of drug abuse: An overview exploring the harmful potential of drug abuse both to the individual and to society. ISRN Addiction, 1-6. https://doi.org/10.1155/2013/450348

Fromson, J. A., \& Shah, R. M. (2014). The role of spirituality in physician recovery from alcoholism. Alcoholism Treatment Quarterly, 32(2-3), 237-247. https://doi.org/10.1080/07347324.2014.907053

GBD 2016 Alcohol Collaborators. (2018). Alcohol use and burden for 195 countries and territories, 1990-2016: A systematic analysis for the Global Burden of Disease Study 2016. Elsevier. The Lancet, 392(10152), 1015-1035. https://doi.org/10.1016/S0140-6736(18)31310-2

Gémes, K., Forsell, Y., Janszky, I., László, K. D., Lundin, A., Ponce De Leon, A., Mukamal, K. J. \& Moller, J. (2019). Moderate alcohol consumption and depression - a longitudinal population-based study in Sweden. Acta Psychiatrica Scandinavica, 139(6), 526-535. https://doi.org/10.1111/acps.13034

Greenfield, S. F., Back, S. E., Lawson, K. \& Brady, K. T. (2010). Substance abuse in women. The Psychiatric Clinics of North America, 33(2), 339-355. https://doi.org/10.1016/j.psc.2010.01.004

Groshkova, T., Best, D., \& White, W. (2011). Recovery Group Participation Scale (RGPS): Factor structure in alcohol and heroin recovery populations. Journal of Groups in Addiction \& Recovery. 6(1-2), 76-92. https://doi.org/10.1080/1556035X.2011.571132

Haroosh, E. \& Freedman, S. (2017). Posttraumatic growth and recovery from addiction. European Journal of Psychotraumatology, 8(1), 1369832. https://doi.org/10.1080/20008198.2017.1369832

Hjorthøj, C., Østergaard, M. L. D., Benros, M. E., Toftdahl, N. G., Erlangsen, A., Andersen, J. T., \& Nordentoft, M. (2015). Association between alcohol and substance use disorders and all-cause and cause-specific mortality in schizophrenia, bipolar disorder, and unipolar depression: a nationwide, prospective, register-based study. The Lancet Psychiatry, 2(9), 801-808. https://doi.org/10.1016/s2215-0366(15)00207-2

Holman, C. D., English, D. R., Milne E., \& Winter M. G. (1996). Meta-analysis of alcohol and allcause mortality: A validation of NHMRC recommendations. Medical Journal of Australia. 164(3), 141-145. https://doi.org/10.5694/j.1326-5377.1996.tb122011.x

Chen, H.-M., Chen, V. C.-H., Hsiao, H.-P., Weng, Y.-P., Hsu, Y.-T., Weng, J.-Ch., Su, J.-A. \& Chen, Y.-L. (2019). Correlations and correlates of post-traumatic growth and post-traumatic stress symptoms in patients with breast cancer. Neuropsychiatric Disease and Treatment, 15, 3051-3060. https://doi.org/10.2147/ndt.s218450

Ibrahim, F., Kumar, N., \& Samah, B. A. (2011). Self-efficacy and relapsed addiction tendency: An empirical study. Social Sciences, 6(4), 277-282. https://doi.org/10.3923/sscience.2011.277.282

Joseph, S. (2012). What doesn't kill us: The new psychology of posttraumatic growth. Piatkus Little Brown.

Jung, C. G. (1992). Analytická psychologie, její teorie a praxe. Academia.

Kalina, K. (2003). Drogy a drogové závislosti. Úrad vlády ČR.

Kalina, K. (2013). Psychoterapeutické systémy a jejich uplatněnív adiktologii. Grada. 
Kang, S. K., Kim, H. J., \& Shin, S. (2018). A qualitative case study on recovery and personal growth in Korean drug addicts. Journal of Social Service Research, 44(3), 279-290. https://doi.org/10.1080/01488376.2018.1457593

Kavenská, V. (2009). Smysl života v kontextu závislosti na alkoholu. E-psychologie, 3(1), 1-11. https://e-psycholog.eu/pdf/kavenska.pdf

Keyes, C. L. M. (2002). The mental health continuum: From languishing to flourishing in life. Journal of Health and Social Behavior. 43, 207-222. https://doi.org/10.2307/3090197

Khursheed, M. \& Shahnawaz, M. G. (2020). Trauma and post-traumatic growth: Spirituality and selfcompassion as mediators among parents who lost their young children in a protracted conflict. Journal of Religion and Health. https://doi.org/10.1007/s10943-020-00980-2

Kirkner, A. \& Ullman, S. E. (2019). Sexual assault survivors' post-traumatic growth: Individual and community-level differences. Violence Against Women, 107780121988801. https://doi.org/10.1177/1077801219888019

Kuswanto, C. N., Sharp, J., Stafford, L. \& Schofield, P. (2020). Posttraumatic growth as a buffer and a vulnerability for psychological distress in mothers who are breast cancer survivors. Journal of Affective Disorders, 275, 31-37. https://doi.org/10.1016/j.jad.2020.06.013

Lahav, Y., Ginzburg, K., \& Spiegel, D. (2019). Post-traumatic growth, dissociation, and sexual revictimization in female childhood sexual abuse survivors. Child Maltreatment, 107755951985610. https://doi.org/10.1177/1077559519856102

Larsson, S. C., Wallin, A., \& Wolk, A. (2018). Alcohol consumption and risk of heart failure: Metaanalysis of 13 prospective studies. Clinical Nutrition, 37(4), 1247-1251. https://doi.org/10.1016/j.clnu.2017.05.007

Laudet, A. B. (2007). What does recovery mean to you? Lessons from the recovery experience for research and practice. Journal of Substance Abuse Treatment, 33(3), 243-256. https://doi.org/10.1016/j.jsat.2007.04.014

Linley, P. A., \& Joseph, S. (2004). Positive change following trauma and adversity: A review. Journal of Traumatic Stress, 17, 11-21. https://doi.org/10.1023/B:JOTS.0000014671.27856.7e

Liu, Z., Doege, D., Thong, M. S. Y., \& Arndt, V. (2020). The relationship between posttraumatic growth and health-related quality of life in adult cancer survivors: A systematic review. Journal of Affective Disorders, 276, 159-168. https://doi.org/10.1016/j.jad.2020.07.044

Lookatch, S. J., Wimberly, S. A., \& McKay, J. R. (2019). Effects of social support and 12-step involvement on recovery among people in continuing care for cocaine dependence. Substance Use \& Misuse, 54(13), 2144-2155. https://doi.org/10.1080/10826084.2019.1638406

Lovibond, S. H., \& Lovibond, P. F. (1995). Manual for the depression anxiety stress scales. Psychology Foundation of Australia.

Mareš, J. (2012). Posttraumatický rozvoj člověka. Grada.

Marsden, J., Gossop, M., Stewart, D., Best. D., Farrel, M., Lehmann, P., Edwards, C. \& Strang. J. (1998). The Maudsley Addiction Profile (MAP): a brief instrument for assessing treatment outcome. Addiction. 93, 1857-1868. https://doi.org/10.1046/j.1360-0443.1998.9312185711.x

Mazor, Y., Gelkopf, M., Mueser, K. T. \& Roe, D. (2020). Posttraumatic Growth in Psychosis: Challenges to the assumptive world. Psychological Trauma: Theory, Research, Practice, and Policy, 12(1), 3-10. https://doi.org/10.1037/tra0000443

McGaffin, B., Deane, F., Kelly, P. \& Ciarrochi, J. (2015). Flourishing, languishing and moderate mental health: Prevalence and change in mental health during recovery from drug and alcohol problems. Addiction Research and Theory, 23(5), 351-360. https://doi.org/10.3109/16066359.2015.1019346

McGaffin, B., Lyons, G. \& Deane, F. (2013). Self-forgiveness, shame, and guilt in recovery from drug and alcohol problems. Substance Abuse, 34(4), 396-404. https://doi.org/10.1080/08897077.2013.781564

McLellan, A. T., Kushner, H., Metzger, D., Peters, R., Smith, I., Grissom, G., \& Argeriou, M. (1992). The fifth edition of the Addiction Severity Index. Journal of Substance Abuse Treatment, 9, 199213. https://doi.org/10.1016/0740-5472(92)90062-S 
Mee-Lee, D., Schulman, G. D. \& Fishman, M. (2001). ASAM Patient Placement Criteria for the Treatment of Substance-Related Disorders. American Society of Addiction Medicine.

Miovský, M. (2017). Pozitivní vliv umírněného pití alkoholu na lidské zdraví: marné hledání třetí strany mince. Adiktologie, 17(2), 148-160.

Mo, C., Deane, F. P., Lyons, G. C. B. \& Kelly, P. J. (2013). Factor analysis and validity of a short six item version of the Desires for Alcohol Questionnaire. Journal of Substance Abuse Treatment. 44, 557-564. https://doi.org/10.1016/j.jsat.2012.12.002

Mokhtari, M. R., Alavi, M. Pahlavanzadeh, S., Weimand, B. M., Visentin, D., \& Cleary, M. (2019). Comparison of the effectiveness of a 12 step substance use recovery program on quality of life. Nursing and Health Sciences, 22(2), 390-397. https://doi.org/10.1111/nhs.12668

Národní monitorovací středisko pro drogy a závislosti. (2017). Výroční zpráva o stavu ve věcech drog $v$ České republice v roce 2016.

National Institute on Alcohol Abuse and Alcoholism. (2003). Alcohol: A Women's Health Issue. Bethesda, MD: National Institutes of Health. https://www.una.edu/manesafety/Alcohol\%20Brochures/WomanHealthIssue.pdf.

Nešpor K. \& Csémy L. (2006). Spiritualita v medicíně a u návykových nemocí. Časopis lékařò českých, 145(9), 743-745.

Newcomb M. D., \& Locke T. (2005) Health, social, and psychological consequences of drug use and abuse. In Z. Sloboda (eds), Epidemiology of Drug Abuse. Springer. https://doi.org/10.1007/0-38724416-6_4

Nikmanesh, Z., Baluchi, M. H., \& Pirasteh Motlagh, A. A. (2017). The role of self-efficacy beliefs and social support on prediction of addiction relapse. International Journal of High Risk Behaviors and Addiction, 6(1), e21209. https://doi.org/10.5812/ijhrba.21209

O’Leary, V. E., Alday, C. S., \& Ickovics, J. R. (1998). Models of life change and posttraumatic growth. In R. G. Tedeschi, C. L. Park, \& L. G. Calhoun (eds.), Posttraumatic growth: Positive changes in the aftermath of crisis. Lawrence Erlbaum Associates, 127-152.

Pardini, D. A., Plante, T. G., Sherman, A., \& Stump, J. E. (2000). Religious faith and spirituality in substance abuse recovery. Journal of Substance Abuse Treatment, 19(4), 347-354. https://doi.org/10.1016/s0740-5472(00)00125-2

Park, C. L., Cohen, L. H. \& Murch, R. L. (1996). Assessment and prediction of stress-related growth. Journal of Personality, 64, 71-105. https://doi.org/10.1111/j.1467-6494.1996.tb00815.x

Peele, S. \& Brodsky, A. (2000). Exploring psychological benefits associated with moderate alcohol use: A necessary corrective to assessments of drinking outcomes? Drug and Alcohol Dependence, 60(3), 221-247. https://doi.org/10.1016/s0376-8716(00)00112-5

Plante, T. G., \& Boccaccini, M. T. (1997). The Santa Clara Strength of Religious Faith Questionnaire. Pastoral Psychology. 45, 375-386. https://doi.org/10.1080/13607863.2014.917606

Polito, V., \& Stevenson, R. J. (2019). A systematic study of microdosing psychedelics. PloS One, 14(2). e0211023. https://doi.org/10.1371/journal.pone.0211023

Psaltopoulou, T., Sergentanis, T. N., Ntanasis-Stathopoulos, I., Tzanninis, I. G., Tsilimigras, D. I., \& Dimopoulos, M. A. (2018). Alcohol consumption and risk of hematological malignancies: A metaanalysis of prospective studies. International Journal of Cancer, 143(3), 486-495. https://doi.org/10.1002/ijc.31330

Ries, R. K., Fiellin, D. A., Miller, S. C. \& Saitz, R. (2014). The ASAM Principles of Addiction Medicine. Lippincott Williams \& Wilkins.

Riesel, P. (2017). Př́spěvek ke studiu vlivu spirituality na vznik a rozvoj závislosti na drogách a na následné změny identity postižených osob a možné způsoby léčby. Adiktologie, 17(1), 56-62.

Rong, C., Lee, Y., Carmona, N. E., Cha, D. S., Ragguett, R.-M., Rosenblat, J. D., Mansur, R. B., Ho, R. C. \& McIntyre, R. S. (2017). Cannabidiol in medical marijuana: Research vistas and potential opportunities. Pharmacological Research, 121, 213-218. https://doi.org/10.1016/j.phrs.2017.05.005

Ross, S. (2018). Therapeutic use of classic psychedelics to treat cancer-related psychiatric distress. International Review of Psychiatry, 30(4), 1-14. https://doi.org/10.1080/09540261.2018.1482261

Roubal, J., \& Vybíral, Z. (2010). Současná psychoterapie. Portál. 
Ruprich, J. (2015). Přehled národnich vodítek pro stř́dmou konzumaci alkoholických nápojů: nizkorizikové dávky alkoholu. Praha: Státní zdravotní ústav. http://www.szu.cz/uploads/CZVP/Prehled_voditek_pro_stridmou_konzumaci_alkoholu_etanolu_.pdf

Samková, D., \& Dolejš, M. (2014). Smysl života u závislých na alkoholu a jejich osobnostní charakteristiky. Adiktologie, 14(2), 158-166.

Sayed, B. A., \& French, M. T. (2016). To your health! Re-examining the health benefits of moderate alcohol use. Social Science \& Medicine, 167, 20-28. https://doi.org/10.1016/j.socscimed.2016.08.034

Sears, S. R., Stanton, A. L., \& Danoff-Burg, S. (2003). The yellow brick road and the emerald city: Benefit finding, positive reappraisal coping, and posttraumatic growth in women with early-stage breast cancer. Health Psychology, 22(5), 487-497. https://doi.org/10.1037/0278-6133.22.5.487

Seligman, M. E. P., \& Csikszentmihalyi, M. (2000). Positive Psychology - An Introduction. American Psychologist, 55, 5-14. https://doi.org/10.1037/0003-066X.55.1.5

Seo, H. \& Lee, O. (2020). Mediating role of post-traumatic stress disorder in post-traumatic growth in adults who experienced the 2017 Pohang Earthquake. Journal of Affective Disorders, 263, 246-251. https://doi.org/10.1016/j.jad.2019.11.162

Sheehan, D., Lecrubier, Y., Harnett-Sheehan, K., Amorim, P., Janavs, J., \& Weiller, E., Hergueta, T., Baker, R., \& Dunbar, G. C. (1998). The Mini International Neuropsychiatric Interview (MINI): The development and validation of a structured diagnostic psychiatric interview. Journal of Clinical Psychiatry. 59, 22-33. http://www.psychiatrist.com/JCP/article/Pages/1998/v59s20/v59s2005.aspx

Scheier, M. F., \& Carver, C. S. (1985). Optimism, coping, and health: Assessment and implications of generalized outcome expectancies. Health Psychology. 4, 219-247. https://doi.org/10.1037//02786133.4.3.219

Scheier, M. F., Wrosch, C., Baum, A., Cohen, S., Martire, L. M., Matthews, K. A., \& Zdaniuk, B. (2006). The Life Engagement Test: Assessing purpose in life. Journal of Behavioral Medicine, 29, 291-298. https://doi.org/10.1007/s10865-005-9044-1

Schepis, T. S., Klare, D. L., Ford, J. A., \& McCabe, S. E. (2020). Prescription drug misuse: Taking a lifespan perspective. Substance Abuse: Research and Treatment, 14, 117822182090935. https://doi.org/10.1177/1178221820909352

Schulte, M. T., \& Hser, Y.-I. (2013). Substance use and associated health conditions throughout the lifespan. Public Health Reviews, 35(2). https://doi.org/10.1007/bf03391702

Sklar, S. M., \& Turner, N. E. (1999). A brief measure for the assessment of coping self-efficacy among alcohol and other drug users. Addiction. 94, 723-729. https://doi.org/10.1046/j.13600443.1999.94572310.x

Slade, M., Rennick-Egglestone, S., \& Blackie, L. (2019). Post-traumatic growth in mental health recovery: qualitative study of narratives. BMJ Open, 9. https://doi.org/10.1136/bmjopen-2019029342

Slezáčková, A. (2012). Průvodce pozitivní psychologií. Grada.

Stoto, M. A. (2015). Drug safety meta-analysis: Promises and pitfalls. Drug Safety, 38(3), 233-243. https://doi.org/10.1007/s40264-015-0268-x

Substance Abuse and Mental Health Services Administration. (2018). https://www.samhsa.gov/data/

Sussman, S., Dent, C. W., \& McCullar, W. J. (2000). Group self-identification as a prospective predictor of drug use and violence in high risk youth. Psychology of Addictive Behaviors. 14,192196. https://doi.org/10.1037/0893-164X.14.2.192

Tedeschi, R. G., \& Calhoun, L. G. (1995). Trauma and transformation: Growing in the aftermath of suffering. Sage.

Tedeschi, R. G., \& Calhoun, L. G. (1996). The posttraumatic growth inventory: Measuring the positive legacy of trauma. Journal of Traumatic Stress, 9, 455-471. https://doi.org/10.1007/BF02103658

Tedeschi, R. G., Park, C. L. \& Calhoun, L. G. (1998). Posttraumatic growth: Positive changes in the aftermath of crisis. Erlbaum. 
Tennen, H., \& Affleck, G. (2002). Benefit-finding and benefit-reminding. In C. R. Snyder \& S. J. Lopez, S. J. (eds.), Handbook of positive psychology. Oxford University Press.

The World Health Organisation. (2004). Quality of life -WHOQOL BREF. http://www.who.int/substance_abuse/research_tools/en/english_whoqol.pdf

The WHOQOL Group. (1998). The World Health Organization quality of life assessment (WHOQOL): development and general psychometric properties. Social Science \& Medicine, 46, 1569-1585. https://doi.org/10.1016/s0277-9536(98)00009-4

Walsh, Z., Gonzalez, R., Crosby, K. S., Thiessen, M. S., Carroll, C., \& Bonn-Miller, M. O. (2017). Medical cannabis and mental health: A guided systematic review. Clinical Psychology Review, 51, 15-29. https://doi.org/10.1016/j.cpr.2016.10.002

Whealin, J. M., Pitts, B., Tsai, J., Rivera, C., Fogle, B. M., Southwick, S. M., \& Pietrzak, R. H. (2020). Dynamic interplay between PTSD symptoms and posttraumatic growth in older military veterans. Journal of Affective Disorders. https://doi.org/10.1016/j.jad.2020.03.020

White, W. L. (2007). Addiction recovery: its definition and conceptual boundaries. The Journal of Substance Abuse Treatment (33), 229-241. https://doi.org/10.1016/j.jsat.2007.04.015

Whiteman, H. (2015). Alcohol: does it really offer health benefits? Medical News Today. https://www.medicalnewstoday.com/articles/292179.php

Wills, T. A. \& Cleary, S. D. (1996). How are social support effects mediated? A test with parental support and adolescent substance use. Journal of Personality and Social Psychology, 71, 937-952. https://doi.org/10.1037//0022-3514.71.5.937

Witbrodt, J., Kaskutas, L. A., \& Grella, C. E. (2015). How do recovery definitions distinguish recovering individuals? Five typologies. Drug and Alcohol Dependence, 148, 109-117. https://doi.org/10.1016/j.drugalcdep.2014.12.036

Wolt, R. \& Valachová, T. (2019). Charakter pitia alkoholu u žien liečených pre závislost' od alkoholu v centre pre liečbu drogových závislostí Banská Bystrica. Česká a slovenská psychiatrie, 115(6), 261-267.

Woodward, C., \& Joseph, S. (2003). Positive change processes and posttraumatic growth in people who have experienced childhood abuse: understanding vehicles of change. Psychology and Psychotherapy: Theory, Research and Practice, 76, 267-283. https://doi.org/10.1348/147608303322362497

Worley, J. (2020). Spirituality in recovery from substance use disorders: What to know to inform practice. Journal of Psychosocial Nursing and Mental Health Services. 58(9), 14-17. https://doi.org/10.1080/01612840.2016.1245375

Yalom, I. D., \& Lieberman, M. A. (1991). Bereavement and heightened existential awareness. Psychiatry: Interpersonal and Biological Processes, 54(4), 334-345. https://doi.org/10.1080/00332747.1991.11024563

Yalom, I. D. (2012). Chvála psychoterapie. Portál.

Zeidner, M. \& Kampler, S. (2019). Memory traces of childhood exposure to terror attack and resilience and post-traumatic growth in adulthood. Personality and Individual Differences, 109719. https://doi.org/10.1016/j.paid.2019.109719

Zhou, X., Zhen, R., \& Wu, X. (2019). Trajectories of posttraumatic growth among adolescents over time since the Wenchuan earthquake. Journal of Adolescence, 74, 188-196. https://doi.org/10.1016/j.adolescence.2019.06.009

Zimet, G. D., Dahlem, N. W., Zimet, S. G., \& Farley, G. K. (1988). The multidimensional scale of perceived social support. Journal of Personality Assessment. 52, 30-41.

https://doi.org/10.1207/s15327752jpa5201_2 


\section{O autorkách}

Mgr. Alena Olivová je studentkou doktorského studia psychologie na Filozofické fakultě Masarykovy univerzity $v$ Brně. Pracuje v doléčovacím centru jako terapeutka osob se závislostí na alkoholu a vambulanci klinické psychologie. Tomu předcházela práce $\mathrm{v}$ terénních službách sklientelou závislou na pervitinu a heroinu. Je frekventantkou psychoterapeutického výcviku v Gestalt terapii. Ve výzkumu se zaměřuje na propojení psychoterapie a adiktologie.

\section{Kontaktní údaje:}

Email: 415354@mail.muni.cz

Korespondenční adresa: Čechova 238, Lednice 69144

Doc. PhDr. Alena Slezáčková, Ph.D. je docentkou psychologie na Lékařské fakultě Masarykovy univerzity $\mathrm{v}$ Brně, kde se výzkumně i výukově věnuje tématům především z oblasti psychologie zdraví a pozitivní psychologie. Ve výzkumu se zaměřje na zkoumání souvislostí naděje, osobní pohody a všímavosti s duševním a tělesným zdravím.

Email: alena.slezackova@med.muni.cz

Olivová, A., \& Slezáčková, A. (2021). Osobnostní rozvoj př́i zotavování se ze závislosti na omamných látkách. E-psychologie, 15(1), 69-89. https://doi.org/10.29364/epsy.393 